\title{
Translation and cultural adaptation of Patient Perceptions of Hemodialysis Scale in Brazil
}

\author{
Tradução e adaptação cultural da Patient Perceptions of Hemodialysis Scale no Brasil \\ La traducción y adaptación cultural de Patient Perceptions of Hemodialysis Scale al portugués de Brasil
}

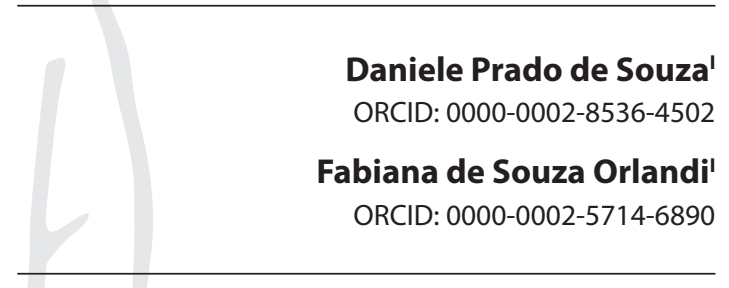

'Federal University of São Carlos São Carlos-SP, Brazil.

How to cite this article:

Souza DP, Orlandi FS. Translation and cultural adaptation of Patient perceptions of hemodialysis scale in Brazil. Rev Bras Enferm. 2019;72(2):314-20. doi: http://dx.doi.org/10.1590/0034-7167-2018-0052

Corresponding Author:

Fabiana de Souza Orlandi

E-mail: forlandi@ufscar.br

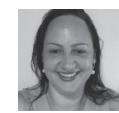

Submission: 02-3-2018

Approval: 08-08-2018

\begin{abstract}
Objective: To translate and adapt the Patient Perceptions of Hemodialysis Scale (PPHS) to the Brazilian context. Method: A methodological study, in which the stages of initial translation, synthesis of translations, back translation, evaluation by an expert committee and pre-test of the PPHS were performed. Results: Two initial translations by independent translators, experienced in the health area and fluent in English. Subsequently, the synthesis of the translations was carried out, and this synthesis was back translated to the original language (American English).The translated and backtranslated versions were evaluated by an expert committee made up of six PhD experts from the health area. The judges' evaluations resulted in content validity indexes for each item of the scale, and 7 of the 36 items had to be revised. Subsequently, a pretest was carried out with 20 participants, who considered the instrument intelligible. Conclusion: The PPHS is adequately translated and adapted to Brazilian Portuguese. Descriptors: Chronic Renal Insufficiency; Renal Dialysis; Psychometrics; Quality of life; Self-evaluation.
\end{abstract}

\section{RESUMO}

Objetivo: Traduzir e adaptar a Patient Perceptions of Hemodialysis Scale (PPHS) para o contexto brasileiro. Método: Estudo metodológico, no qual foram realizadas as etapas de tradução inicial, síntese das traduções, retrotradução, avaliação do Comitê de Especialistas e pré-teste da PPHS. Resultados: Foram realizadas duas traduções iniciais por tradutores independentes, com experiência em tradução de textos na área da saúde e fluentes em inglês. Posteriormente realizou-se a síntese das traduções, sendo esta retrotraduzida para o idioma original (inglês americano).As versões traduzidas e a retrotraduzida foram avaliadas pelo Comitê de Especialistas, constituído por seis doutores da área da saúde. As avaliações dos juízes resultaram nos índices de validade de conteúdo para cada item da escala, sendo que 7 dos 36 itens precisaram ser revistos. Posteriormente foi realizado o pré-teste com 20 participantes, os quais consideraram o instrumento compreensível. Conclusão: A PPHS encontra-se traduzida e adaptada para o português brasileiro.

Descritores: Insuficiência Renal Crônica; Diálise Renal; Psicometria; Qualidade de Vida; Autoavaliação.

\section{RESUMEN}

Objetivo: Traducir y adaptar la Patient Perceptions of Hemodialysis Scale (PPHS) al contexto brasileño. Método: Estudio metodológico, en el que se llevaron a cabo las etapas de traducción inicial, síntesis de las traducciones, retraducción, evaluación de la comisión de expertos y preprueba de la PPHS. Resultados: Dos traducciones iniciales fueron hechas por traductores independientes, con experiencia en traducción de textos en el campo de la salud y con fluidez en inglés. Posteriormente se llevó a cabo la síntesis de las traducciones, siendo retraducida al idioma original (inglés americano). Las versiones traducidas y retraducidas fueron evaluadas por la Comisión de expertos, compuesta por seis especialistas con posgrado en el campo de la salud. Las evaluaciones de los expertos implicaron el índice de validez de contenido para cada ítem de la escala, en la cual debían revisarse 7 de los 36 ítems. Después se realizó la preprueba con 20 participantes, quienes consideraron comprensible el instrumento. Conclusión: La PPH está traducida y adaptada al portugués brasileño.

Descriptores: Insuficiencia Renal Crónica; Diálisis Renal; Psicometría; Calidad de Vida; Autoevaluación. 


\section{INTRODUCTION}

Chronic Kidney Disease (CKD) is defined as the result of irreversible and progressive kidney damage, caused by problems that render the kidneys unfit to perform their functions. CKD is considered a global public health problem ${ }^{(1)}$.

Among CKD treatment modalities, the most common is hemodialysis, a therapeutic process that removes metabolic waste, with the goal of correcting changes in the body environment, through blood circulation using a purpose-built equipment ${ }^{(1)}$.

The Brazilian chronic dialysis survey by Sesso, Lopes, Thomé, Lugon and Martins ${ }^{(2)}$ states that the estimated total number of patients with CKD undergoing dialysis in Brazil is 122,825. Among these, 112,999 (92\%) are undergoing hemodialysis, while 9,826 (8\%) are undergoing peritoneal dialysis. Thus, at the national level, hemodialysis is the most widely used renal replacement therapy.

Thus, the total number of patients with CKD undergoing dialysis in Brazil went through a significant increase of 31.5 thousand patients in the last 5 years (from 91,314 in 2011). The national dialysis prevalence rate in 2016 was 596 patients per million population (pmp), ranging from 344 patients pmp in the North to 700 patients pmp in the Southeast ${ }^{(2)}$.

CKD requires changes in daily habits that influence the patient's quality of life. The patient's pro-activity in facing the new condition is paramount ${ }^{(3)}$, considering its social, physical, psychological, and emotional nature, as well as its implications over habits, sex life, independence, and autonomy.

It is of the utmost importance for people involved in hemodialysis patient care (health care team, family members, and caregivers) to understand - through qualified listening, alertness and acute perception - the needs and feelings emerging from the disease and its treatment, in order to provide more humanized approaches to care.

In order to evaluate the perceptions of CKD patients undergoing hemodialysis treatment, in 2012 Twomey validated the Patient Perceptions of Hemodialysis Scale (PPHS) ${ }^{(4)}$, created by Gregory, Way, Hutchinson, Barrett and Parfrey in $1998^{(5)}$. Twomey points out that the PPHS allows the measurement of the patient's state in terms of physical health, social support and adjustment to CKD and hemodialysis.

A study conducted by the same author in 2013 to evaluate the responsiveness of PPHS, concluded that this scale is reliable, valid and responsive to physical changes and critical events, providing health professionals with a viable method to evaluate important health factors and predict the quality of results ${ }^{(6)}$.

In 2015, Twomey confirmed, through psychometric testing and validation, the legitimacy and reliability of the scale to measure the specific concerns of patients undergoing hemodialysis, regarding the disease itself and the way they experience life while coping with it. The study also discussed the way the scale identifies how patients interpret the meaning of their physical and psychosocial health, as well as their adjustment to life on hemodialysis( ${ }^{(7)}$.

In a recent study ${ }^{(8)}$, Twomey, with the objective of refining the scale by means of statistical analyzes, concluded that the subscales of the PPHS were able to accurately ascertain the main characteristics of the individual, and that it could be considered a valid indicator of the perceptions of patients undergoing hemodialysis. The study also pointed out that with the use of
PPHS, the health team would be able to assess the situation the disease and its treatment, as well as the patient's perception on formal social support, adjustment to life on hemodialysis, and healthcare interventions. In summary, the PPHS has become a valid scale and a suitable measure for a better adjustment of the patient to CKD and hemodialysis.

Therefore, the process of translation, cultural adaptation and, in the future, validation of this scale for the Brazilian context is of paramount importance and will provide a valuable tool for clinical monitoring of the part of the Brazilian population suffering from CKD and undergoing hemodialysis.

\section{OBJECTIVE}

To translate and adapt the Patient Perceptions of Hemodialysis Scale (PPHS) to the Brazilian context.

\section{METHODS}

\section{Ethical aspects}

All ethical guidelines involving human research have been respected. The project has been approved by the Human Research Ethics Committee of the Federal University of São Carlos. The author of the PPHS scale authorized its translation, cultural adaptation and validation for the Brazilian context.

\section{Design, stages and location of the study}

This was a methodological study of the translation and cultural adaptation of the PPHS to Brazil, which followed the steps recommended by Guillemin and collaborators ${ }^{(9)}$ :

1. Initial Translation - translation of the original version of the PPHS (in American English) to Brazilian Portuguese, by two independent translators.

2. Synthesis of Translations - definition of a consensual version of the PPHS in a meeting between translators and researchers.

3. Back translation - translation of the consensus version from Brazilian Portuguese to American English, by two translators unaware of the objectives of the study and who have English as their mother tongue.

4. Committee review - committee members were selected through curriculum analysis in the Lattes Platform, with the requirement of fluency in the original language of the scale. These were physicians and health experts, with experience in nephrology and in the translation and adaptation of instruments. As soon as the invitation was accepted, members were sent all documents in need of evaluation, together with an explanatory letter regarding the study's objectives, as well as details concerning the instrument. The signing of an Informed Consent Form was also required. The committee's judges evaluated the instrument, suggested modifications and gave pertinent opinions for language adaptation, in order to provide the best comprehension on the part of the respondents. These suggestions were expressed by means of an evaluation table.

The evaluations of the judges were analyzed and the necessary modifications were made, resulting in a pre-final version to be 
used in the pre-test phase. The pre-test was performed later with CKD patients undergoing hemodialysis. It is worth noting that most of the major changes suggested by the experts were related to the intelligibility of certain words or expressions, considering the low level of education of the instrument's target population.

5. Pre-test - the revised version of the PPHS was evaluated by CKD patients from a Renal Replacement Therapy Unit (UTRS), in the interior of the State of São Paulo, who were undergoing hemodialysis. This evaluation took three weeks, and had the goal of verifying the instrument's clarity and intelligibility, and identifying possible errors.

6. Presentation and evaluation of the reports of the PPHS cross-cultural adaptation process - consisting in the evaluation of all reports produced in the previous stages.

It is important to point out that in steps 4, 5 and 6 the semantic, idiomatic, conceptual and experiential equivalences of the PPHS were considered, as recommended by Alexandre and Coluci in $2011^{(10)}$ : semantic equivalence refers to the meaning of words (grammar and vocabulary); idiomatic equivalence refers to idiomatic and colloquial expressions; experiential equivalence addresses the adequacy of evoked situations to the target cultural context, and conceptual equivalence refers to the validity of explored concepts in the target culture.

\section{Sample and inclusion and exclusion criteria}

The pre-test was performed with 20 participants, according to the following inclusion criteria: age equal to or greater than 18 years; CKD medical diagnosis; to be on hemodialysis for the past six months, at least; to have no cognitive impairment, as ascertained by the Mini Mental State Examination (MMSE). The exclusion criterion was: to have a disability that makes it impossible to perform the interview, such as hearing or visual impairment.

\section{Study protocol}

Contact with the chosen individuals was carried out at the UTRS, where they were informed about the purpose of the study, and all their questions were answered. After verbal consent was obtained, participants were requested to sign the Informed Consent Form, followed by the individual interview in a private room of the UTRS, with the initial application of the MEEM. With the confirmation that they had no cognitive alteration, the instruments for sociodemographic characterization and evaluation of PPHS items were applied - the former with the goal of characterizing the respondents in regards to age, sex, ethnicity, marital status and schooling.

The PPHS is comprised of 36 questions, all answerable through a five-point Likert scale. Items are rated from 0 to 4 , "with 0 indicating that individuals have no incidence of the symptom or no satisfaction/concern/confidence with the item and 4 indicating that they almost always experience the symptom or that they are extremely satisfied/concerned/confident about the item/ statement."(4)

The PPHS evaluates the three main factors of patients' experiences: illness and treatment, social support (formal and informal) and treatment adjustment. It is also comprised of five subscales: emotional well-being, psychosocial distress, nursing support, physician support and physical health. It is worth mentioning that the instrument was created to monitor and evaluate factors that may have an effect on the patients' experience of the illness and of CKD treatment, and that determine their quality of life ${ }^{(6)}$.

\section{Analysis of results and statistics}

The data collected in this study were placed in an Excel data sheet and later imported to the Statistical Package for Social Science (SPSS) software version 22.0. The software was used to perform the analyzes below on the frequency of responses for pre-test participants' sociodemographic characteristics and the averages of the age variable.

The Content Validity Index (CVI) of the items of the PPHS was also calculated. To this end, the expert committee answered to a four-point Likert scale in respect to each PPHS item. Thus: $1=$ not equivalent; 2 = somewhat equivalent; 3 = quite equivalent; 4 = highly equivalent. For the reading of the CVI, the criterion proposed by Lynn in 1986 ${ }^{(11)}$ — which recommends a value above 0.78 for six or more judges - was employed. The index score is calculated by dividing the sum of items that received " 3 " or " 4 " expert's scores by the total number of responses.

\section{RESULTS}

The original version was translated by two independent and qualified translators, in order to guarantee the best quality, as well as the detection of errors and divergences of interpretation concerning ambiguous terms.

A consensual version was formulated by translators and researchers to solve the possible divergences or ambiguous interpretations, based on the two translations. It was then back translated into the original language (American English), in order to improve the quality of the pre-final version and detect translation errors. The consensual version was evaluated by the experts committee, which analyzed the PPHS versions in order to produce a pre-final version, modified and adapted to serve as a replica of the instrument in Brazil.

The CVI was calculated for each question of the scale, as detailed in the Methods section. Among the scale's 36 items, as shown in Table 1, 15 had CVI $=1 ; 14$ had CVI $=0.83 ; 4$ had CVI = $0.67 ; 2$ had $\mathrm{CVI}=0.33$, and 1 had $\mathrm{CVI}=0.17$.

The seven items which presented CVI below 0.78 were revised, as shown in Table 2.

Table 1 - Content Validity Index of the items of the Patient Perceptions of Hemodialysis Scale after review by the expert committee

\begin{tabular}{cc}
\hline Items & CVI* \\
\hline $1,2,3,11,12,13,19,20,21,29,30,32,33,34$ e 35 & 1 \\
$4,5,6,7,9,10,14,15,16,17,23,24,28$ e 36 & 0,83 \\
$18,22,25$ e 26 & 0,67 \\
8 e 27 & 0,33 \\
31 & 0,17 \\
\hline
\end{tabular}

Note: ${ }^{*}$ Content Validity Index 
The pre-final version of the PPHS was evaluated by pre-test participants, 11 men and nine women, most of them white (55\%), married (50\%) and with incomplete primary education (Table 3 ). The mean age of participants was 47.9 years. It should be noted that such characteristics are in accordance with data from the Brazilian Dialysis Census ${ }^{(2)}$, since the majority of Brazilian individuals with CKD undergoing dialysis are men, white, married, and have low educational levels.

Pre-test respondents considered the PPHS items to be clear, comprehensible, and relevant to patients' experiences of CKD and hemodialysis. Some participants also emphasized the importance of the instrument's questions about the health team responsible for their care.

Throughout the process of cross-cultural adaptation, the reports were evaluated to ensure that all previous recommended steps had been followed, in accordance with the proposed objectives.

\section{DISCUSSION}

The process of translation and cross-cultural adaptation of an instrument is hardly trivial, since it requires not only the literal translation of words, but also a respect for the culture of the individuals to whom the instrument is intended ${ }^{(12)}$. Attention should be paid not only to the translation of words per se, but also to semantic, idiomatic, experiential and conceptual equivalence ${ }^{(9)}$.

In this context, for a better-quality translation to be obtained, it must be developed by two qualified and independent translators, preferably from the country where the instrument was developed, thus dominating the language pair in its semantic, idiomatic, cultural and conceptual aspects. The consensual version establishes an agreement regarding the possible divergences or ambiguous interpretations found in the two translations ${ }^{(9)}$.

Table 2 - Original version, consensual version, and pre-final version of the Patient Perceptions of Hemodialysis Scale, after review by the expert committee

PPHS* items

to know what to do if you become ill on
dialysis?

18

22

How often do you feel depressed (i.e., feeling down, fed-up, frustrated) about your illness and long-term treatment requirements?

26

How often do you experience fears or worries about unexpected illness/ dialysis events (e.g., sudden drop in blood pressure, clotting of access sites, breathing problems due to too much fluid)?

How often do you feel that depending on others makes you feel useless (i.e., selfesteem, self-worth)?
How confident are you that you will come to terms with your illness (i.e., accepting)?
O quanto você está confiante de que os(as) enfermeiros(as) e técnicos(as) têm conhecimento e habilidades para saber os procedimentos corretos caso passe mal durante a diálise?

O quanto você está preocupado (a)com a piora de sua saúde, independente do que você ou os médicos façam?

O quanto você fica preocupado(a) em expressar suas necessidades para enfermeiros(as), técnicos(as) ou médicos(as), por causa da proximidade física de outras pessoas durante a diálise?

Com que frequência você fica deprimido (isto é, se sente triste, farto, frustrado) sobre sua doença e as exigências do tratamento no longo prazo?

Com que frequência você sente medo ou preocupação com eventos inesperados relacionados à doença/ diálise (por exemplo, queda súbita da pressão arterial, coagulação dos locais de acesso, problemas respiratórios por causa do excesso de fluídos)?

Com que frequência você sente que depender dos outros te faz com que se sinta inútil (isto é, autoestima, respeito próprio)?

O que você está confiante de que irá se adaptar à sua doença (isto é, aceitará sua doença)?
Pre-final version
O quanto você sente confiança no conhecimento e habilidades que a Equipe de Enfermagem possui, caso você passe mal durante a diálise?

O quanto você se preocupa com sua saúde, independente do que você ou a equipe de saúde façam?

O quanto você fica preocupado(a)em falar sobre suas necessidades para a equipe de saúde, porque outras pessoas estão por perto durante a diálise?

Com que frequência você fica deprimido (isto é, triste, cansado, frustrado) por causa da sua doença e das exigências do tratamento a longo prazo?

Com que frequência você sente medo ou preocupação com eventos inesperados relacionados à doença/ diálise (por exemplo, queda súbita da pressão arterial, coagulação no acesso de diálise, problemas na respiração por causa do excesso de líquidos)?

Com que frequência você sente que depender dos outros faz com que se sinta inútil (isto é, baixa autoestima, diminuição do respeito próprio)?

O quanto você está confiante de que irá se adaptar à sua doença (isto é, aceitará sua doença)? 
Table 3 - Descriptive statistics of the evaluated sample

\begin{tabular}{|c|c|c|c|}
\hline Variable & Categories & $\mathbf{n}$ & $\%$ \\
\hline Gender & $\begin{array}{c}\text { Male } \\
\text { Female }\end{array}$ & $\begin{array}{c}11 \\
9\end{array}$ & $\begin{array}{l}55 \\
45\end{array}$ \\
\hline Ethnicity & $\begin{array}{c}\text { White } \\
\text { Brown } \\
\text { Black }\end{array}$ & $\begin{array}{c}11 \\
6 \\
3\end{array}$ & $\begin{array}{l}55 \\
30 \\
15\end{array}$ \\
\hline Marital Status & $\begin{array}{l}\text { Married } \\
\text { Single } \\
\text { Divorced } \\
\text { Widower }\end{array}$ & $\begin{array}{l}10 \\
6 \\
3 \\
1\end{array}$ & $\begin{array}{c}50 \\
30 \\
15 \\
5\end{array}$ \\
\hline Schooling & $\begin{array}{l}\text { Illiterate } \\
\text { Incomplete primary education } \\
\text { Complete primary education } \\
\text { Incomplete secondary school } \\
\text { Complete secondary school } \\
\text { Complete higher education }\end{array}$ & $\begin{array}{l}1 \\
9 \\
2 \\
2 \\
4 \\
2\end{array}$ & $\begin{array}{c}5 \\
45 \\
10 \\
10 \\
20 \\
10\end{array}$ \\
\hline
\end{tabular}

Back translation makes it possible to improve the quality of the final version and to detect translation errors. In order to improve the quality of the back translation, the selected translators must be fluent in both languages (the instrument's original language and the target language), as well as have English as their mother tongue ${ }^{(9)}$.

We conclude that the stages of translation, synthesis of translations and back translation of the PPHS were satisfactorily developed, with the back-translated version being approved by the author of the original scale.

In order to obtain the final version of the instrument, an expert committee needs to be set up to review and compare all translations, modifying and adapting them to produce a replica of the instrument, to be used in Brazil. The members of the committee should be bilingual, specialists in the health area, and experienced in the subject matter ${ }^{(10)}$.

For this study, the committee was comprised of six members who fully fulfilled all the aforementioned attributions. It should be noted that it was their responsibility to evaluate the instrument as a whole, determining its scope, i.e., whether each domain and concept was adequately covered by the set of items, and whether all dimensions were included. In addition, the experts also ensured that the final version of the instrument was fully understandable, assessing its cultural equivalence. Thus, it was the discretion of the committee to suggest modifications and initial orientations for improving the instrument's format, altering or rejecting inappropriate items and/or developing news ${ }^{(10)}$. Experts can also confirm whether the instrument has items that clearly delimit the subject under study, and collaborate in the uniformization of the terms included in the scale ${ }^{(13)}$.

In the case of PPHS, seven of the 36 items received CVI scores below 0.78 and were revised, following suggestions from the experts committee. Thus, the pre-final version of the PPHS was more understandable from the standpoint of the target population-CKD patients undergoing hemodialysis.

Thus, the pre-test takes place after stage 4 of the review by the judges committee, in order to evaluate the equivalence between the original version and the pre-final version, with the application of the instrument to a certain sample of the population, aiming at detecting possible errors and confirming the intelligibility of all items $s^{(9)}$. In the original scale-building study, Gregory and Way, with the objective of refining the number of PPHS items, used the "face validity" step. This involved, in addition to four specialists in nephrology and one teacher, two patients with chronic kidney disease who were undergoing hemodialysis ${ }^{(5)}$. In this context, it becomes clear how important it is for the population to which the instrument is geared towards to participate in its elaboration, since this improves its construction and adaptation.

In regard to the sociodemographic profile of pre-test participants, 55\% were men, with a mean age of 47.9 years, $55 \%$ declared themselves white, $50 \%$ were married, and $45 \%$ had incomplete primary education.

In a study with the goal of associating sociodemographic data with the quality of life of CKD patients undergoing hemodialysis, Marinho, Oliveira, Borges, Fernandes and Silva formed a sample composed of 105 patients from a nephrology service in the interior of Bahia, and observed that $57.1 \%$ of the sample was comprised of men, $80 \%$ had schooling up to 8 years of age, $46.7 \%$ were married, and that the mean age was 49.9 years ${ }^{(14)}$. Another study, developed by Lopes, Fukushima, Inouye, Pavarini and Orlandi, evaluated the health-related quality of life of CKD patients on dialysis, with a sample composed of 101 patients at a specialized service in the state of São Paulo, and showed that $49.5 \%$ of the sample was comprised of white people ${ }^{(15)}$. These data are similar to those obtained in this study's pre-test.

Patients considered the PPHS to be a clear, comprehensible and pertinent instrument to evaluate their experiences with CKD and hemodialysis, and in this sense the instrument was able to fulfill the pre-test goals stipulated by Guillemin, Bombardier and Beaton. These authors explain that the pre-test technique makes it possible to ascertain the sample's comprehension of the instrument, and may employ questions to the patient, at the end of each question or item, about their understanding of the situation, besides encouraging them to express their doubts, in order to arrive at equivalent results ${ }^{(9)}$.

The last stage of cross-cultural adaptation is the presentation and evaluation of the process reports produced in the previous stages by those responsible for the research, ensuring that the reports' recommendations were followed ${ }^{(9)}$. 
The reports were developed and evaluated in a satisfactory manner, allowing the subsequent step-analysis of the psychometric properties of the scale-to be adequately carried out in the future.

\section{Limitations of this study}

A limitation for this study was the need for the participants to have no cognitive alterations, which excluded such patients from the evaluation of the PPHS. People with disabilities such as severe visual impairment that barred them from participating in the interview were also not included.

\section{Contributions to the area of nursing, health or public policy}

This research contributes to professional health practice by providing a tool that assists nursing professionals and other members of the health team to evaluate the experience of CKD patients undergoing hemodialysis treatment, their perception of the support received by the nursing and medical team, and their emotional well-being, physical health and psychosocial distress. This makes it possible to qualify the provided care, improving the quality of life of the assisted patients.

\section{CONCLUSION}

Based on the proposed objectives and the obtained results, we conclude that the PPHS is translated and culturally adapted to the Brazilian context. In the future, we intend to analyze the psychometric properties of the PPHS, to make it widely available in Brazil.

\section{FINANCING}

This study was funded by the National Council for Scientific and Technological Development (CNPq) and by the Foundation for Research Support of the State of São Paulo (Fapesp).

\section{REFERENCES}

1. Rudnicki T. Chronic renal patient: Experience of hemodialysis treatment. Contextos Clín [Internet]. 2014 [cited 2017 Dec 16];7(1):105-16. Available from: http://www.revistas.unisinos.br/index.php/contextosclinicos/article/view/ctc.2014.71.10/4124

2. Sesso RC, Lopes AA, Thomé FS, Lugon JR, Martins CT. Brazilian Chronic Dialysis Survey 2016. J Bras Nefrol [Internet]. 2017 [cited 2018 Jan 22];39(3):261-66. Available from: http://www.scielo.br/pdf/jbn/v39n3/pt_0101-2800-jbn-39-03-0261.pdf

3. Lins SMSB, Leite JL, Godoy S, Fuly PSC, Araújo STC, Silva IR. Cultural adaptation of the end-stage renal disease adherence questionnaire for hemodialysis patients. Rev Bras Enferm [Internet]. 2017 [cited 2017 Dec 16];70(6):1234-41. Available from: http://www.scielo.br/pdf/reben/ v70n6/pt_0034-7167-reben-70-06-1169.pdf

4. Twomey JC. Psychometric testing of the patient perception of hemodialysis scale. St. John's. [Thesis] - Memorial University of Newfoundland [Internet]. 2012 [cited 2017 Dec 2016]. Available from: http://research.library.mun.ca/2402/1/Twomey_JCreina.pdf

5. Gregory DM, Way CY, Hutchinson TA, Barrett BJ, Parfrey PS. Patients' perceptions of their experiences with ESRD and hemodialysis. Qualit Health Res [Internet]. 1998 [cited 2018 Jan 29];8(6):764-83. Available from: http://journals.sagepub.com/doi/ abs/10.1177/104973239800800604

6. Twomey JC, Parfrey PS, Barrett BJ, Churchill DN, Way CY. Responsiveness of the patient's perception of hemodialysis scale. J ACITN [Internet]. 2014 [cited 2017 Dec 16];24(2):33-44. Available from: http://europepmc.org/abstract/med/25276989

7. Twomey JC, Barrett BJ, Way CY, Churchill, DN, Parfrey PS. Psychometric Psychometric properties of the patient's perception of life on hemodialysis scale. J Nurs Meas[Internet]. 2015 [cited 2017 Dec 16];23(1):72-81. Available from: https://www.ncbi.nlm.nih.gov/ pubmed/25985496

8. Twomey JC, Way CY, Parfrey PS, Churchill DN, Barrett BJ. Instrument refinement: the patient's perceptions of life on hemodialysis scale. Sage Open [Internet]. 2017 [cited 2018 Jan 25];7(4):2158244017742952. Available from: http://journals.sagepub.com/doi/ pdf/10.1177/2158244017742952

9. Guillemin F, Bombardier C, Beaton D. Cross-cultural adaptation of health related quality of life measures: literature review and proposed guidelines. J Clin Epidemiol [Internet]. 1993 [cited 2017 Dec 16];46(12):1417- 32. Available from: http://www.jclinepi.com/ article/0895-4356(93)90142-N/pdf

10. Alexandre NMC, Coluci MZO. Content validity in the development and adaptation processes of measurement instruments. Ciênc Saúde Coletiva [Internet]. 2011 [cited 2017 Dec 16];16(7):3061-8. Available from: http://www.scielo.br/pdf/csc/v16n7/06.pdf

11. Lynn MR. Determination and quantification of content validity. Nurs Res [Internet]. 1986 [cited 2018 Jan 25];35(6):382-6. Available from: https://journals.Iww.com/nursingresearchonline/citation/1986/11000/determination_and_quantification_of_content.17.aspx

12. Jensen R, Cruz DALM, Tesoro MG, Lopes MHBM. [Translation and cultural adaptation for Brazil of the Developing Nurses'Thinking model]. Rev Latino-Am Enfermagem [Internet]. 2014 [cited 2017 Dec 16];22(2):197-203. Available from: http://www.scielo.br/pdf/rlae/v22n2/ pt_0104-1169-rlae-22-02-00197.pdf Portuguese.

13. Dalla Nora CR, Zoboli E, Vieira MM. Validation by experts: importance in translation and adaptation of instruments. Rev Gaúcha Enferm [Internet]. 2017 [cited 2018 Jan 22];38(3):1-9. Available from: http://www.seer.ufrgs.br/index.php/RevistaGauchadeEnfermagem/article/ view/64851/44620 
14. Marinho CLA, Oliveira JF, Borges JES, Fernandes FECV, Silva RS. Association between sociodemographic characteristics and quality of life of chronic renal patients on hemodialysis. Rev Cuidarte [Internet]. 2018 [cited 2018 Jan 22];9(1):2017-29. Available from: https://www. revistacuidarte.org/index.php/cuidarte/article/view/483/918

15. Lopes JM, Fukushima RLM, Inouye K, Pavarini SCI, Orlandi FS. Quality of life related to the health of chronic renal failure patients on dialysis. Acta Paul Enferm [Internet]. 2014 [cited 2017 Dec 16];27(3):230-6. Available from: http://www.redalyc.org/pdf/3070/307031542007.pdf 